\title{
Twenty Years of Drilling the Deepest Hole in Ice
}

\author{
by Nikolay I. Vasiliev, Pavel G. Talalay, and Vostok Deep Ice Core Drilling Parties
}

doi:10.2204/iodp.sd.11.05.2011

\section{Introduction}

Ice sheets and glaciers contain stratified ancient ice that fell as snow years to millions of years ago. The dust particles, soluble chemicals, and gases trapped in the ice can be used to study how Earth's climate system operated in the past. However, this requires deep ice coring. The retrieved glacial ice can be utilized for an accurate measure of past greenhouse gases with climate clearly documented in the same core. Therefore, ice core data have become crucial to our understanding of past climate change and to making assessments about future climate.

The Soviet Antarctic research station Vostok was founded at the center of the East Antarctic Ice Sheet $\left(78^{\circ} 28^{\prime} \mathrm{S}\right.$, $106^{\circ} 48^{\prime} \mathrm{E}, 3488$ m.a.s.l.) in 1957 (Fig. 1). This place turned out to be the coldest on Earth; the lowest reliably measured temperature of $-89.2^{\circ} \mathrm{C}$ was recorded on 21 July 1983 . In addition, by good fortune Vostok was set above the southern end of the largest subglacial lake in Antarctica, discovered in 1996 by Russian and British scientists (Kapitsa et al., 1996) while drilling deep boreholes.

Deep ice core drilling at Vostok station began in 1970 . In the 1970 s a set of open uncased holes were drilled by a thermal drill system suspended on cable. The deepest dry hole in ice reached $952.4 \mathrm{~m}$ (Hole \#1, May 1972). It was concluded that for drilling at greater depths it is necessary to

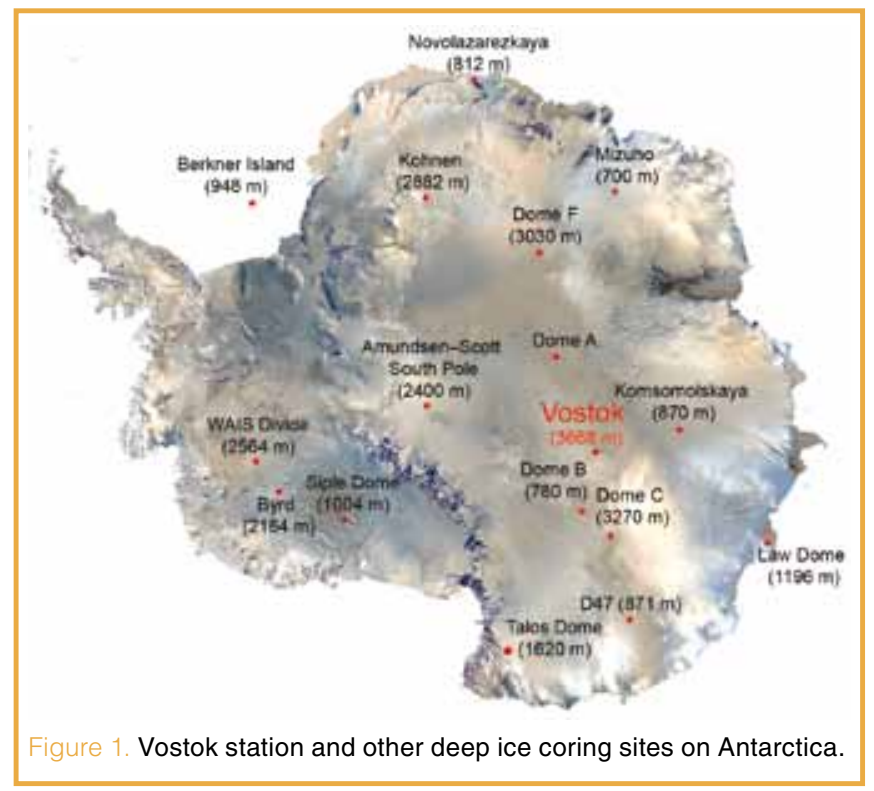

prevent hole closure by filling of the borehole with a fluid. Thus, from 1980 on new thermal and electromechanical drill systems working in fluid were used. Two boreholes reached depths of more than $2000 \mathrm{~m}$. Hole \#3G-2 was deepened to $2201.7 \mathrm{~m}$ depth in 1985 (Kudryashov, 1989) and Hole \#4G-2 to $2546.4 \mathrm{~m}$ depth in 1989 (Kudryashov et al., 1994). Drilling of both holes was aborted because of stuck tools.

\section{Drilling Operations 1990-2010}

Drilling a new deep Hole \#5G started in February 1990, using a TELGA-14M thermal drill for dry coring to a depth of $120 \mathrm{~m}$ (Table 1). Thereafter, the thermal drill TBZS-152M for fluid-filled holes was used down to $2502.7 \mathrm{~m}$, at which point it became stuck during tripping out due to hole closure caused by insufficient fluid pressurization. As recovery attempts failed, the cable was pulled out of the top of the drill (Tchistiakov et al., 1994).

About 35 meters of artificial core was dropped on top of the stuck drill, creating a base for a new offset hole. The TBZS-132 thermal drill was used to sidetrack and drill Hole \#5G-1 (Fig. 2). The main difference between the thermal drills TBZS-132 and TBZS-152M was the outer diameter of the drill head and the tubing used for the core barrel and water tank (Kudryashov et al., 1998). In 1993 Hole \#5G-1 reached $2755.3 \mathrm{~m}$ depth, a new record for thermal drilling in ice.

During the summer season 1993-1994, the borehole diameter was enlarged from $180 \mathrm{~mm}$ to $220 \mathrm{~mm}$ in the upper portion using an electromechanical reaming technique. The hole was cased with fiberglass tubing with a thermal shoe at the bottom, and was sealed at a depth of $120 \mathrm{~m}$ to prevent fluids from entering the hole through an upper permeable zone.

In November 1994, drilling operations in Hole \#5G-1 were resumed with the KEMS-135 electromechanical drill (Fig. 3), reaching $3350 \mathrm{~m}$ depth by January 1996 . An average penetration of $2.8 \mathrm{~m}$ was achieved per run, but at the depth greater than $2930 \mathrm{~m}$, progress decreased dramatically because of frequent sticking and jamming (Kudryashov et al., 2002).

With season 1996-97 the drilling operations were reduced to the short Antarctic summer because a vehicle traverse failed to reach Vostok in the previous season. When 
drilling of Hole \#5G-1 was continued until January 1998 (reaching $3623 \mathrm{~m}$ depth), several design changes allowed an increase in the efficiency of ice destruction and drilling chips removal from the bottom of the hole.

After an eight-year hiatus, this hole was reopened in the summer 2005-06 (Vasiliev et al., 2007). A new geometry of cutters for penetration of "warm ice" improved the drilling process. As a result, Hole \#5G-1 was deepened to $3658 \mathrm{~m}$ (January 2007), with an average core length of $0.7-0.8 \mathrm{~m}$ per run (Fig. 4). At this depth the drill became stuck at the bottom of the hole. A drill team that remained at Vostok station over winter filled the lower hole with eighty liters of an antifreeze agent using a special fluid barrel with an electromagnetic valve. The drill was captured with an overshot gripper and was lifted to surface in the first attempt before the water-glycol solution was removed from the hole. In May 2007 drilling continued, and different lengths of core barrels were applied to ensure proper functioning of an anti-torque system in cavity intervals. A total of fifty-five runs were required between $3658 \mathrm{~m}$ and $3668 \mathrm{~m}$.

Unfortunately, during the hole enlargement in October 2007 , the core barrel suddenly dropped to the bottom of the hole. All attempts to recover it failed, and operations did not resume before December 2008. A new deviated hole was drilled using thermal directional drilling to bypass the stuck tools (Vasiliev et al., 2007). The new deviated Hole \#5G-2 was drilled without using any special whipstock because the drill bit is usually pushed into a vertical position.

Deviated drilling started at the depth of $3580 \mathrm{~m}$ using the electromechanical drill KEMS-135 with a special drill head and cutters. The hole was successfully deviated and drilled to $3600 \mathrm{~m}$ where the core with a normal circular cross-section was pulled out. Sidetracking of Hole \#5G-2 for testing purpose showed the high efficiency of this technology.

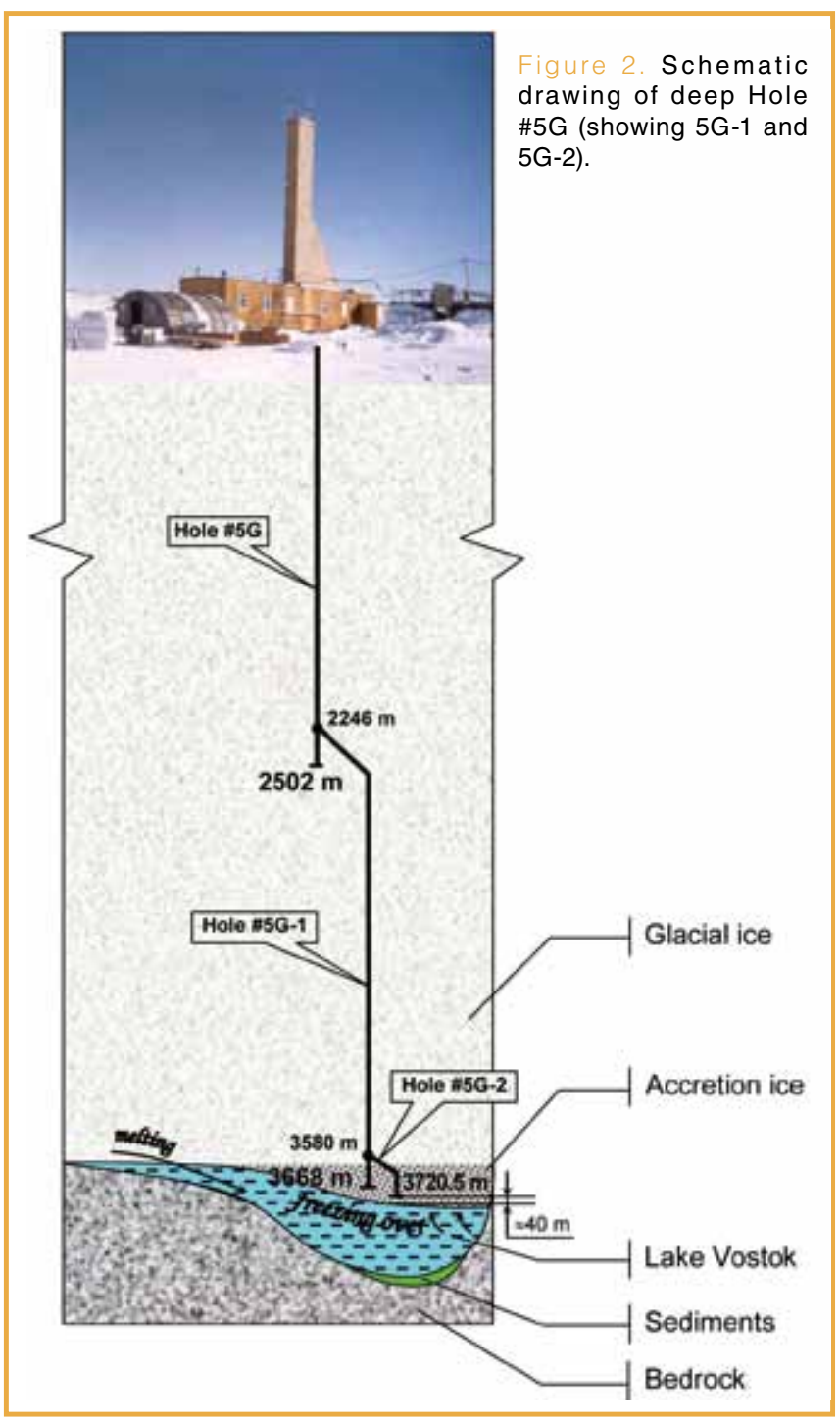

In summer 2009-2010 drilling at Vostok continued, and Hole \#5G-2 was deepened from $3600 \mathrm{~m}$ to $3650 \mathrm{~m}$, nearly achieving the depth reached previously. According to our estimate the distance between the $5 \mathrm{G}-1$ and $5 \mathrm{G}-2$ holes at the

Deep drilling of the Hole \#5G (5G-1, 5G-2) at Vostok station.

\begin{tabular}{|c|c|c|c|c|c|c|}
\hline $\begin{array}{l}\text { Expedition \# } \\
\text { (Year) }\end{array}$ & $\begin{array}{l}\text { Leader of the } \\
\text { drilling team }\end{array}$ & Hole \# & $\begin{array}{l}\text { Interval of drilling } \\
\text { (m) }\end{array}$ & Type of drill & $\begin{array}{c}\text { Mean rate of } \\
\text { penetration } \\
\left(\mathrm{m} \mathrm{h}^{-1}\right)\end{array}$ & $\begin{array}{l}\text { Mean length } \\
\text { of run }(\mathrm{m})\end{array}$ \\
\hline 35 (1990) & A.A. Zemtsov & \multirow{2}{*}{$5 G$} & $0-120$ & TELGA-14M & 1.8 & 1.9 \\
\hline 36 (1991) & A.V. Krasilev & & $1279.8-2502.7$ & TBZS-152M & 2.3 & 3.0 \\
\hline \multirow{2}{*}{37 (1992) } & \multirow{2}{*}{ B.S. Moiseev } & \multirow{9}{*}{$5 G-1$} & 2232-2249.5 & \multirow{3}{*}{ TBZS-132 } & 2.0 & 1.0 \\
\hline & & & $2249.5-2270.7$ & & 2.0 & 2.0 \\
\hline 38 (1993) & V.K. Chistyakov & & $2270.7-2755.3$ & & 1.8 & 2.5 \\
\hline $40(1993)$ & N.I. Vasiliev & & 2755.3-3109 & \multirow{9}{*}{ KEMS-135 } & 8.0 & 2.5 \\
\hline $41^{*}(1995)$ & N.I. Vasiliev & & $3109-3350$ & & 8.0 & 2.2 \\
\hline $42^{*}(1995 / 96)$ & N.I. Vasiliev & & $3350-3523$ & & 8.0 & 2.1 \\
\hline $43^{*}(1997 / 98)$ & N.I. Vasiliev & & $3523-3623$ & & 8.0 & 1.8 \\
\hline $51^{*}(2005 / 06)$ & N.I. Vasiliev & & $3623-3650$ & & 5.0 & 0.8 \\
\hline $52(2007)$ & N.I. Vasiliev & & $3650-3668$ & & 5.0 & 0.7 \\
\hline $54^{*}(2009 / 09)$ & N.I. Vasiliev & \multirow{3}{*}{$5 G-2$} & $3580-3600$ & & - & - \\
\hline $55^{\star}(2009 / 10)$ & N.I. Vasiliev & & $3600-3650$ & & 5.0 & 0.7 \\
\hline $56^{*}(2010 / 11)$ & N.I. Vasiliev & & $3650-3720.5$ & & 5.0 & 0.9 \\
\hline
\end{tabular}

*The drilling was conducted during the austral summer only. 


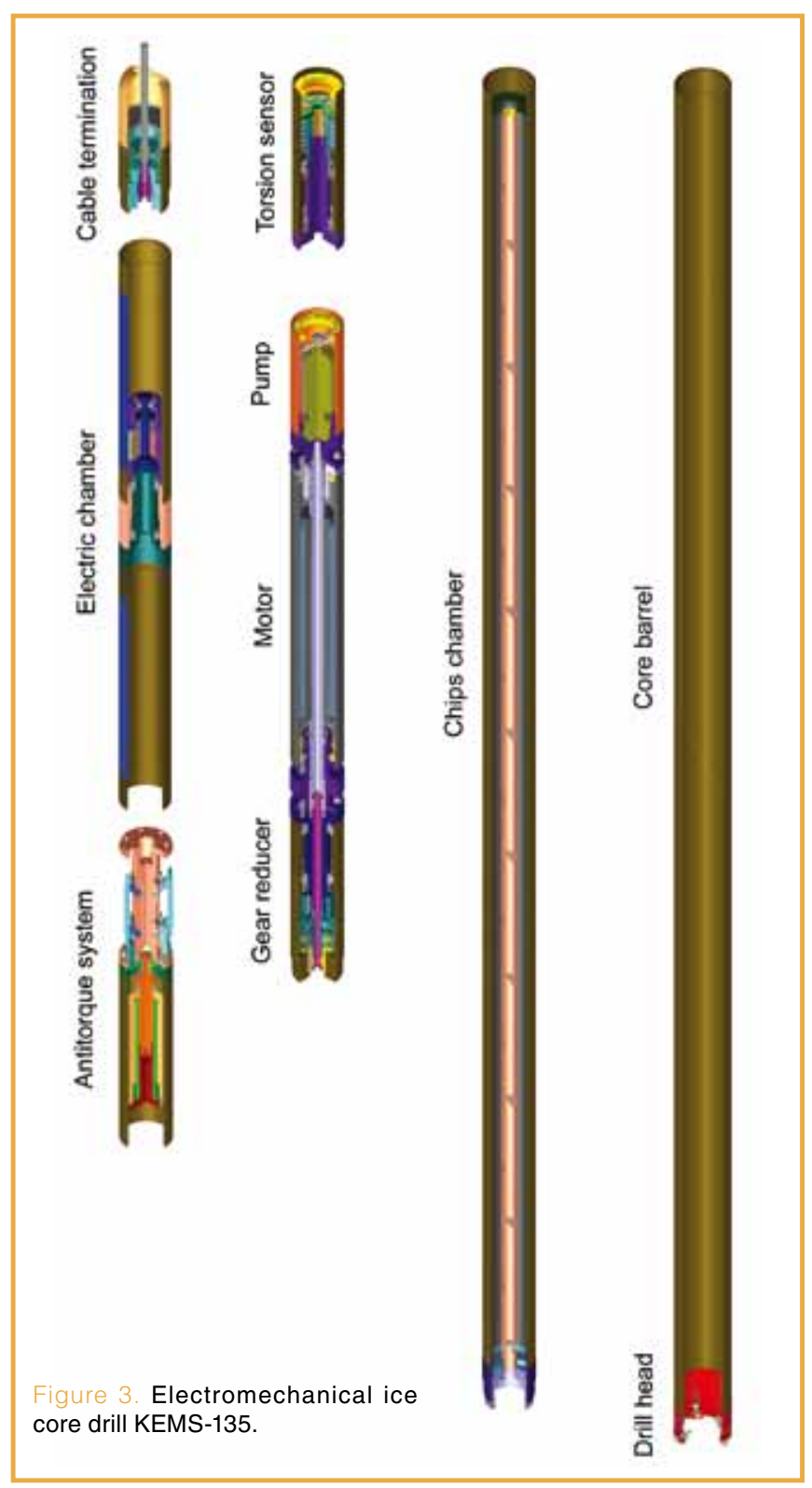

bottom of Hole \#5G-2 is nearly $1.5 \mathrm{~m}$. In the summer season of 2010-11 the Hole \#5G-2 reached the depth of $3720.5 \mathrm{~m}$. The penetration into Lake Vostok will start in the coming years.

\section{Summary of the Scientific Results}

The upper 3310 meters of the Vostok ice core has provided a detailed paleoclimate record for the past four glacial-interglacial cycles occurring about every 100,000 years (Petit et al., 1999). The ice core record extends over the last 420,000 years (Fig. 5). The succession of changes through each climate cycle and termination was similar for the parameters shown; atmospheric and climate properties oscillated within stable limits. In contrast, interglacial periods differ in temporal evolution and duration.

Between $3310 \mathrm{~m}$ and $3539 \mathrm{~m}$, the glacial core is disturbed by bedrock deformation (Souchez et al., 2003). Information on microparticles, crystal sizes, and chemical element distri-
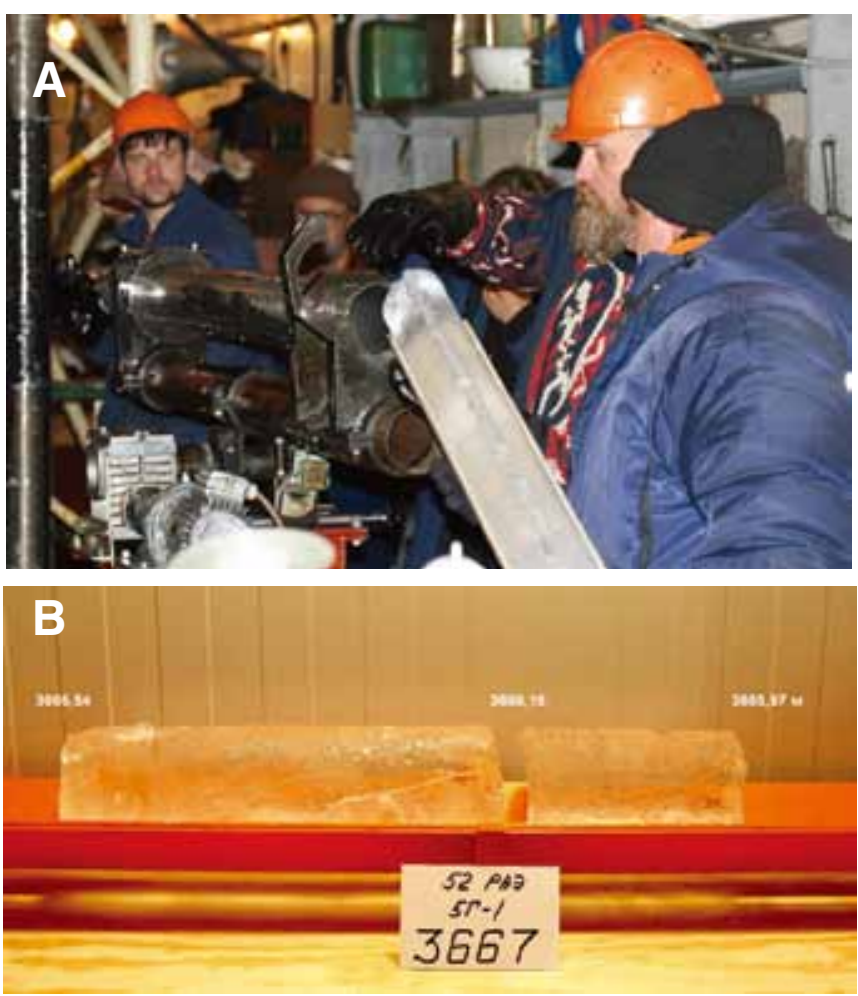

[A] Core recovering from the core barrel (January 2007). [B] Ice core from the deepest layers.

butions in that part of the core shed new light on this deformation process - the ice deformation occurred when the ice was still grounded upstream from Vostok station in a region with subfreezing temperatures.

The deepest portion of the ice core (from $3539 \mathrm{~m}$ to $3668 \mathrm{~m}$ ) has a chemistry, isotopic composition, and crystallography distinctly different from the overlying glacial ice. Geochemical and physical data indicate that it originated from the accretion of subglacial lake water to the underside of the ice sheet (Jouzel et al., 1999). Together with data on ionic chemistry, these ice core data favor an origin of the lake ice by frazil ice generation in a supercooled water plume existing in the lake, followed by accretion and consolidation from subsequent freezing of the host water.

Microbiological studies of the Vostok glacial and accreted ice have indicated that low, but detectable, concentrations of prokaryotic cells (Fig. 6) and DNA are present (Bulat et al., 2004). Many of the bacterial cells are associated with non-living organic and inorganic particulate matter. Some of the viable bacteria were deposited more than 400,000 years ago (Bobin et al., 1994).

According to petro-fabric investigation, development of shear zones in the Antarctic ice sheet is linked with global increase of the dust concentration in the atmosphere during past glacial maxima (Lipenkov et al., 2007). The ice strata forming in these periods are characterized by high impurities of microparticles, small ice-grain sizes, single-maximum c-axis orientation, and low ice viscosity. 


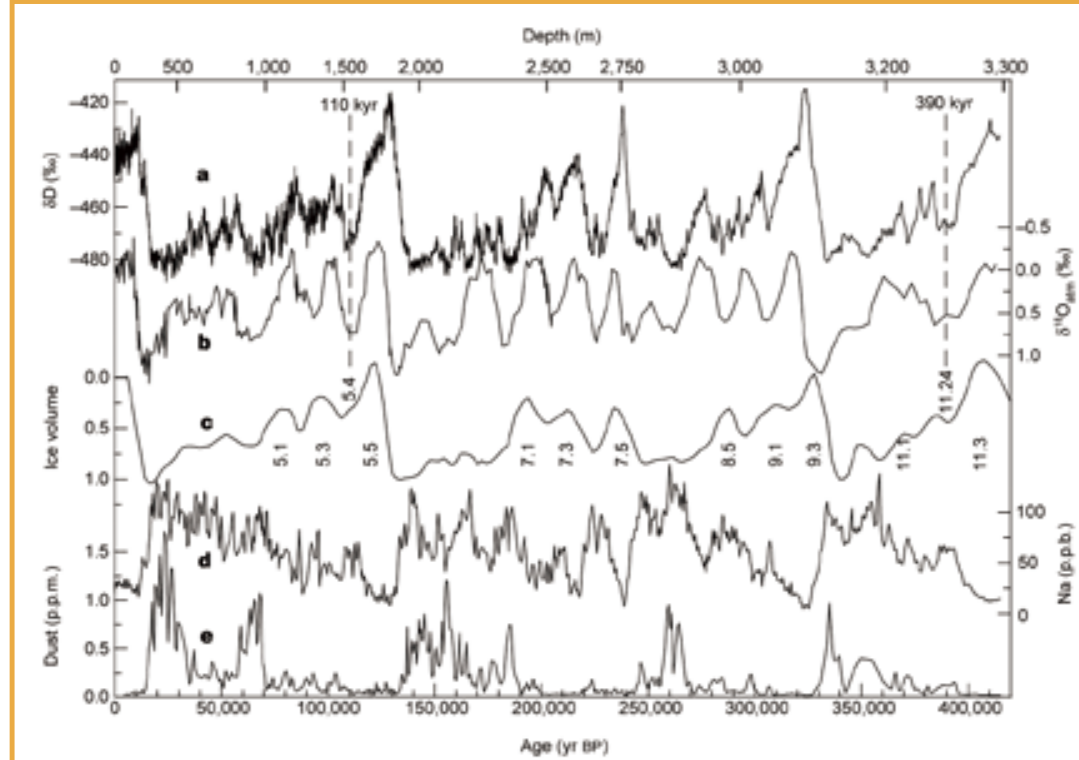

420,000-year profiles of (1) deuterium, (2) $\delta^{18} \mathrm{Oatm},(3)$ seawater $\delta^{18} \mathrm{O}$ (ice volume proxy), (4) sodium, and (5) dust (Petit et al., 1999).

In recent years, advances have been made in understanding and predicting the physical and chemical environment of Lake Vostok based on modeling efforts that set boundary conditions for various attributes. Future studies of the subglacial water properties and searching for ancient life are now important parts of the project at Lake Vostok.

\section{Planning Penetration into Lake Vostok}

With dimensions of $280 \mathrm{~km} \times 50 \mathrm{~km}$ and water depth reaching $1200 \mathrm{~m}$ (Fig. 7) beneath an almost 4-km-thick ice sheet, Lake Vostok is the largest among more than 145 subglacial lakes identified by radar surveys in Antarctica (Siegert et al., 2005). Independent data sources indicate the ice-water interface at Vostok is at $3760 \pm 15 \mathrm{~m}$ depth. The remaining ice between the bottom of Hole \#5G-2 and the lake is about $40 \mathrm{~m}$ thick. We plan to access the lake and sample its waters in three stages (Verkulich et al., 2002).

On the first stage an ecologically inert liquid (e.g., polydimethylsiloxane) will be injected to the hole bottom using a special tanker. It is anticipated that, being heavier than the drilling fluid and lighter than water, this hydrophobic liquid will create a 100-m-thick "buffer-layer" at the lower part of the hole. The hydrostatic pressure at the bottom of Hole \#5G-2 should be slightly lower than the overburden ice pressure.

In a second stage, Hole \#5G-2 will be deepened down to the ice-water interface. The access to the lake will be completed with the coreless thermal drill system TBPO-132

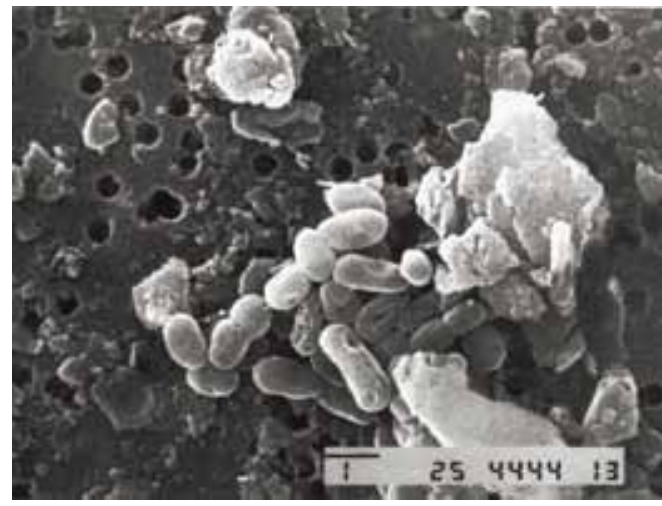

Microbes from Vostok ice core, depth of 2395 m, magnification x14,000 (Bobin et al., 1994).

consisting of two parts: a 2-m-long pilot microdrill generating a 50-mm-diameter hole, followed by the main drill equipped with a 132-mm-diameter thermal drill bit. With this system an average penetration rate of 3-4 $\mathrm{m} \mathrm{hr}^{-1}$ is expected. The drill will be cleaned by the produced melt water which creates a second clean layer separating the bottom of the hole from the drilling fluid. Once the tip of the thin pilot drill punctures the lake surface, the packer will be automatically turned on, and the drill heating and ad-vance will stop. After determination of the pressure differ-ence between hole and lake and maintaining it in a range of 3-4 bars, the thermal drill TBPO-132 will be pulled up. This will allow lake water to enter into the hole and to fill up its lower 30-40 meters.

The third stage could be conducted after checking if the water has frozen in the hole. Then, the frozen lake water will be sampled with electromechanical drill KEMS-135 to a level of about 15-20 $\mathrm{m}$ above the ice-water interface.

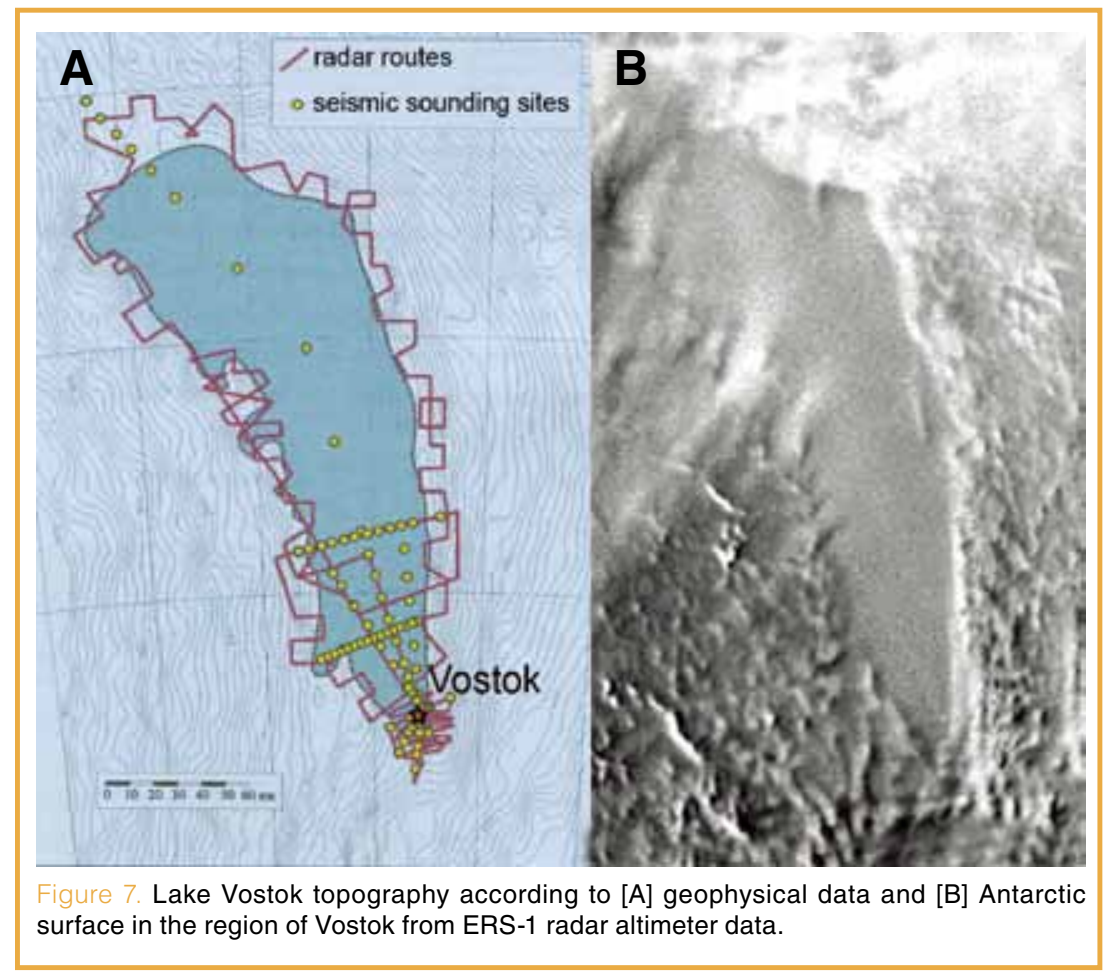


The Lake Vostok penetration approach discussed above has already been tested, though unintentionally, in the course of implementing two international glacial drilling projects in Greenland (North Greenland Ice core Project, NGRIP, 2003) and Antarctica (EPICA drilling at Kohnen station, 2006). In both cases the drilling was performed with routine electromechanical coring of ice without special precautions in the holes filled with kerosene-based drilling fluid similar to that currently used at Vostok. When the base of the ice sheet was reached, the sub-ice water flooded the hole up to several tens of meters above the bed. The water frozen in the NGRIP borehole was drilled in 2004 and later analyzed.

\section{References}

Bobin, N.E., Kudryashov, B.B., Pashkevitch, V.M., Abyzov, S.S., and Mitskevich, I.N., 1994. Equipment and methods of microbiological sampling from deep levels of ice in central Antarctica. Mem. Natl. Inst. Polar Res. Spec. Issue, 49:184-191.

Bulat, S.A., Alekhina, I.A., Blot, M., Petit, J.R., de Angelis, M., Wagenbach, D., Lipenkov, V.Ya., Vasilyeva, L.P., Wloch, D.M., Raynaud, D., and Lukin, V.V., 2004. DNA signature of thermophilic bacteria from the aged accretion ice of Lake Vostok, Antarctica: implications for searching life in extreme icy environments. Int. J. Astrobiol., 3(1):1-12.

Jouzel, J., Petit, J.R., Souchez, R., Barkov, N.I., Lipenkov, V.Ya., Raynaud, D., Stievenard, M., Vassiliev, N.I., Verbeke, V., and Vimeux, F., 1999. More than 200 meters of lake ice above subglacial Lake Vostok, Antarctica. Science, 286(5447): 2138-2141, doi:10.1126/science.286.5447.2138.

Kapitsa, A.P., Ridley, J.K., de Robin, Q.G., Siegert, M.J., and Zotikov, I.A., 1996. A large deep freshwater lake beneath the ice of central East Antarctica. Nature, 381:684-686, doi:10.1038/381684a0.

Kudryashov, B.B., 1989. Soviet experience of deep drilling in Antarctica. In Bandopadhyay, S., and Skudrzyk, F.J. (Eds.), Mining in the Arctic: Proc. 1st Int. Symp. Fairbanks, London (Taylor \& Francis), 113-122.

Kudryashov, B.B., Vasiliev, N.I., and Talalay, P.G., 1994. KEMS-112 electromechanical ice core drill. Mem. Natl. Inst. Polar Res., 49:138-152.

Kudryashov, B.B., Krasilev, A.V., Talalay, P.G., Tchistyakov, V.K., Vassiliev, N.I., Zubkov, V.M., and Lukin, V.V., 1998. Drilling equipment and technology for deep ice coring in Antarctica. In Hall, J. (Ed.) Proc. 7th Symp. Antarctic Logistics and Operations, Cambridge, U.K. (British Antarctic Survey), 205-210.

Kudryashov, B.B., Vasiliev, N.I., Vostretsov, R.N., Dmitriev A.N., Zubkov, V.M., Krasilev, A.V., Talalay, P.G., Barkov, N.I., Lipenkov, V.Ya., and Petit, J.R., 2002. Deep ice coring at Vostok station (East Antarctica) by an electromechanical drill. Mem. Natl. Inst. Polar Res. Spec. Issue, 56:91-102.

Lipenkov, V.Ya., Polyakova, E.V., Duval, P., and Preobrazhenskaya, A.V., 2007. Osobennosti stroenia Antartkticheskogo lednikovogo pokrova $\mathrm{v}$ raione stantsii Vostok po rezul'tatam petrostruktnikh issledovanyi ledyanogo kerna (Structure of Antarctic Ice Sheet in the region of Vostok station according to petro-fabric investigation of ice core). Problemi Arktiki $i$ Antarktiki (Arctic and Antarctic Problems), 76:68-77. (in Russian).

Petit, J.-R., Jouzel, J., Raynaud, D., Barkov, N.I., Barnola, J.-M., Basile, I., Bender, M., Chappellaz, J., Davis, M., Delaygue, G., Delmotte, M., Kotlyakov, V.M., Legrand, M., Lipenkov, V.Y., Lorius, C., Pepin, L., Ritz, C., Saltzman, E., and Stievenard, M., 1999. Climate and atmospheric history of the past 420,000 years from the Vostok ice core, Antarctica. Nature, 399:429-436, doi:10.1038/20859.

Siegert, M.J., Carter, S., Tabacco, I.E., Popov, S., and Blankenship, D.D., 2005. A revised inventory of Antarctic subglacial lakes. Antarct. Sci., 17(3):453-460.

Souchez, R., Jean-Baptiste, P., Petit, J.R., Lipenkov, V.Ya., and Jouzel, J., 2003. What is the deepest part of the Vostok ice core telling us? Earth-Sci. Rev., 60:131-146, doi:10.1016/S00128252(02)00090-9.

Tchistiakov, V.K., Kracilev, A., Lipenkov, V.Ya., Balestrieri, J.Ph., Rado, C., and Petit, J.R., 1994. Behavior of a bore hole drilled in ice at Vostok station. Mem. Natl. Inst. Polar Res. Spec. Issue, 49:247-255.

Vasiliev, N.I., Talalay, P.G., Bobin, N.E., Chistyakov, V.K., Zubkov, V.M., Krasilev, A.V., Dmitriev, A.N., Yankilevich, S.V., and Lipenkov, V.Ya., 2007. Deep drilling at Vostok station, Antarctica: history and last events. Annal. Glaciol., $47: 10-23$.

Verkulich, S.R., Kudryashov, B.B., Barkov, N.I., Vasiliev, N.I., Vostretsov, R.N., Dmitriev, A.N., Zubkov, V.M., Krasiliev, A.V., Talalay, P.G., Lipenkov, V.Ya., Savatyugin, L.M., and Kuz'mina, I.N., 2002. Proposal for penetration and exploration of sub-glacial Lake Vostok, Antarctica. Mem. Natl. Inst. Polar Res. Spec. Issue, 56:245-252.

\section{Authors}

Nikolay I. Vasiliev, Drilling Department, St. Petersburg State Mining Institute, 2, 21 Line, St. Petersburg 199106, Russia, e-mail: vasilev_n@mail.ru.

Pavel G. Talalay, Polar Research Center, Jilin University, No. 6 Ximinzhu Street, Changchun City, Jilin Province 130026, China, e-mail: ptalalay@yahoo.com.

and Vostok Deep Ice Core Drilling Parties (Vladimir M. Zubkov, Valery K. Chistyakov, Andrey N. Dmitriev, Vladimir Ya. Lipenkov, and others)

\section{Related Web Links}

NGRIP: http://www.gfy.ku.dk/ www-glac/ngrip/hovedside_eng.htm

EPICA: http://www.awi.de/en/research/research_divisions/geosciences/glaciology/projects/epica/

\section{Figure Credits}

All photos were provided by members of Vostok drilling team. 